\title{
Tibial tunnel placement in posterior cruciate ligament reconstruction: a systematic review
}

\author{
J.-D. Nicodeme $\cdot$ C. Löcherbach $・$ B. M. Jolles
}

Received: 20 December 2012/ Accepted: 5 June 2013/Published online: 16 June 2013

(C) The Author(s) 2013. This article is published with open access at Springerlink.com

\begin{abstract}
Purpose Reconstruction of the posterior cruciate ligament (PCL) yields less satisfying results than anterior cruciate ligament reconstruction with respect to laxity control. Accurate tibial tunnel placement is crucial for successful PCL reconstruction using arthroscopic tibial tunnel techniques. A discrepancy between anatomical studies of the tibial PCL insertion site and surgical recommendations for tibial tunnel placement remains. The objective of this study was to identify the optimal placement of the tibial tunnel in PCL reconstruction based on clinical studies.

Methods In a systematic review of the literature, MEDLINE, EMBASE, Cochrane Review, and Cochrane Central Register of Controlled Trials were screened for articles about PCL reconstruction from January 1990 to September 2011. Clinical trials comparing at least two PCL reconstruction techniques were extracted and independently analysed by each author. Only studies comparing different tibial tunnel placements in the retrospinal area were included.
\end{abstract}

J.-D. Nicodeme and C. Löcherbach contributed equally to the study and manuscript and should be considered joint first authors.

J.-D. Nicodeme · C. Löcherbach · B. M. Jolles $(\square)$

Department of Orthopaedic Surgery and Traumatology, Site Hôpital Orthopédique, Centre Hospitalier Universitaire Vaudois and University of Lausanne, Avenue Pierre Decker 4,

Lausanne 1011, Switzerland

e-mail: Brigitte.Jolles-haeberli@chuv.ch

J.-D. Nicodeme

e-mail: nicodemejd@hotmail.fr

C. Löcherbach

e-mail: claus.locherbach@chuv.ch
Results This systematic review found no comparative clinical trial for tibial tunnel placement in PCL reconstruction. Several anatomical, radiological, and biomechanical studies have described the tibial insertion sites of the native PCL and have led to recommendations for placement of the tibial tunnel outlet in the retrospinal area. However, surgical recommendations and the results of morphological studies are often contradictory.

Conclusions Reliable anatomical landmarks for tunnel placement are lacking. Future randomized controlled trials could compare precisely defined tibial tunnel placements in PCL reconstruction, which would require an established mapping of the retrospinal area of the tibial plateau with defined anatomical and radiological landmarks.

Level of evidence III.

Keywords Posterior cruciate ligament - Reconstruction · Retrospinal - Systematic review - Tibial tunnel placement

\section{Introduction}

Posterior cruciate ligament (PCL) surgery has evolved significantly in recent years. Based on advanced anatomy and biomechanics, new surgical techniques have been developed to restore native knee kinematics and to control posterior laxity. Single-bundle or double-bundle PCL reconstruction can be performed using a tibial tunnel or inlay technique [40].

The inlay technique was popularized by Berg [3] in 1995 and requires a posterior knee approach. It has the advantage of direct visualization of the insertion of the PCL for an anatomical placement of the graft and avoids the so-called killer turn of the tendon transplant. 
The tibial tunnel technique requires the placement of a tunnel into the retrospinal area. This exclusively arthroscopic surgery avoids posterior capsulotomy, which may induce additional laxity [31]. The entire procedure can be performed on a patient in the supine, flexed-knee position.

Accurate tibial tunnel placement is crucial for successful PCL reconstruction using arthroscopic tibial tunnel techniques. A discrepancy between anatomical studies of the tibial PCL insertion site and surgical recommendations for tibial tunnel placement remains. The results of PCL reconstruction remain inconsistent despite a large choice of operative techniques $[5,15,23]$. There is consensus that, for single-bundle reconstruction, the femoral tunnel should be placed at the anterolateral or at the central part of the footprint, rather than in the posteromedial aspect of the footprint to optimize laxity control (central part) and graft constraint (anterolateral part) [26]. However, recommendations for placement of the tibial tunnel are contradictory. The purpose of this study was to elucidate the optimal placement of the tibial tunnel in PCL reconstruction based on a systematic review of clinical studies, in order to optimize laxity control and improve outcomes.

The objective of this study was to identify the optimal placement of the tibial tunnel in PCL reconstruction based on clinical studies.

\section{Materials and methods}

\section{Literature search}

A search of the Cochrane Bone, Joint and Muscle Trauma Group database of systematic reviews (1990-2011), the Cochrane Central Register of Controlled Trials (September 2011), MEDLINE via PubMed (1990 to September 2011), and EMBASE (1990 to September 2011) using the key words "posterior," "cruciate," "ligament," and "adult" was conducted. It included all clinical trials comparing two different tibial tunnel placements in the retrospinal area for PCL reconstruction using the tibial tunnel technique. The search was limited to studies in adult patients with PCL injury requiring a graft reconstruction. Particular attention was paid to the description of the tunnel placement in the retrospinal area and the anatomical landmarks used for placement. The search was restricted to English, French, Spanish, German, and Italian language publications. The original search strategy is shown in "Appendix".

The three authors independently reviewed the abstracts of all publications identified by the literature search strategy. Studies that did not compare at least two different techniques of PCL reconstruction were excluded from review. All three authors reviewed the remaining publications individually. Consensus was reached through discussion of any disagreements.

Statistical analysis

Counts of retrieved articles were tabulated. Reasons for exclusion were documented.

\section{Results}

The initial search strategy identified 262 publications (Fig. 1). Twelve clinical trials compared at least two different surgical techniques for PCL reconstruction (Table 1); none compared graft placements in the retrospinal area using a tibial tunnel technique. Ten anatomical studies, two radiological studies, and three biomechanical studies evaluating the tibial insertion site of the PCL were identified.

Ten anatomical studies utilized various anatomical landmarks to describe the tibial insertion site of the PCL or its two bundles (Table 2). Girgis et al. [13] located the PCL insertion site in the depression behind the interarticular upper surface of the tibia, with a few millimetres extension onto the adjoining posterior surface of the tibia. Takahashi et al. [38] documented the tibial insertion site of both PCL bundles on 33 tibiae, using the anterior margin of the tibia, the medial border of the tibial plateau, and the vertical distance from the tibial plane as reference points. Using the same anatomical reference points, Tajima et al. [37] reported that the individual tibial insertion sites of both

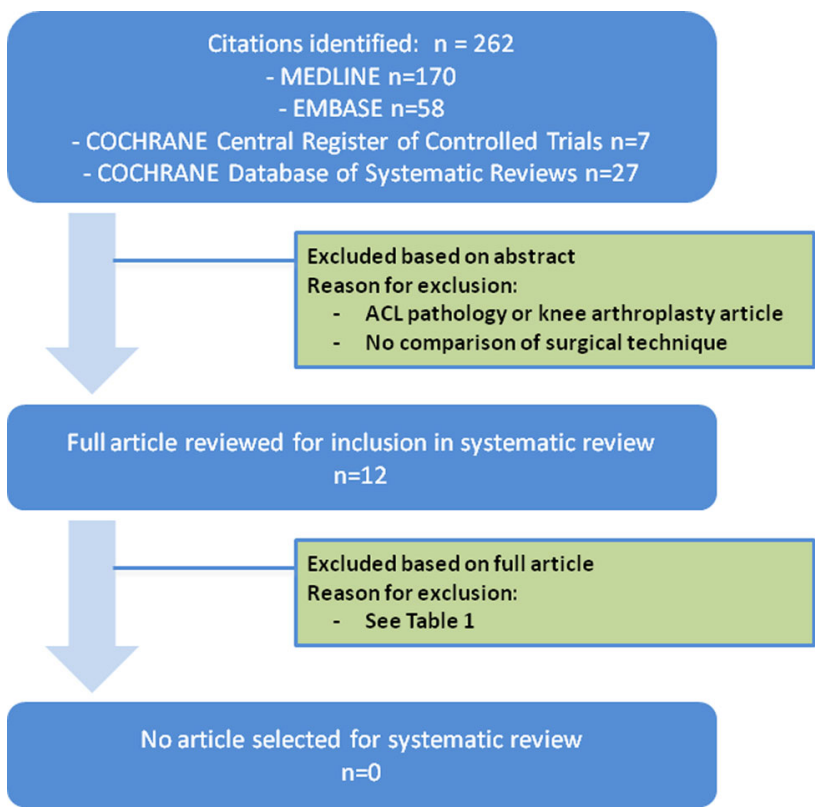

Fig. 1 Search strategy and results for systematic review of the literature 
Table 1 Clinical trials that compared two or more surgical techniques for PCL reconstruction and reasons for exclusion from final analysis

\begin{tabular}{|c|c|c|c|c|c|c|}
\hline & Techniques compared & Study design & $\begin{array}{l}\text { Number } \\
\text { of } \\
\text { patients }\end{array}$ & $\begin{array}{l}\text { Minimum } \\
\text { follow-up }\end{array}$ & Tibial tunnel placement & $\begin{array}{l}\text { Reasons for } \\
\text { exclusion }\end{array}$ \\
\hline Ahn et al. [1] & $\begin{array}{l}\text { Hamstring tendon autograft } \\
\text { versus Achilles tendon } \\
\text { allograft }\end{array}$ & $\begin{array}{l}\text { Retrospective } \\
\text { case-control }\end{array}$ & 36 & 2 Years & No description & $\begin{array}{l}\text { No variation of } \\
\text { tibial tunnel } \\
\text { position }\end{array}$ \\
\hline Chen et al. [5] & $\begin{array}{l}\text { Quadriceps versus quadruple } \\
\text { hamstring PCL reconstruction }\end{array}$ & $\begin{array}{l}\text { Retrospective } \\
\text { case series }\end{array}$ & 49 & 2 Years & $\begin{array}{l}\text { Distal and lateral on } \\
\text { footprint }\end{array}$ & $\begin{array}{l}\text { No variation of } \\
\text { tibial tunnel } \\
\text { position }\end{array}$ \\
\hline $\begin{array}{l}\text { Freeman et al. } \\
\text { [11] }\end{array}$ & $\begin{array}{l}\text { With or without posterolateral } \\
\text { corner reconstruction }\end{array}$ & $\begin{array}{l}\text { Retrospective } \\
\text { case series }\end{array}$ & 17 & 14 Months & No description & $\begin{array}{l}\text { No variation of } \\
\text { tibial tunnel } \\
\text { position }\end{array}$ \\
\hline $\begin{array}{l}\text { Hatayama } \\
\text { et al. [16] }\end{array}$ & $\begin{array}{l}\text { Single- versus double-bundle } \\
\text { PCL reconstruction }\end{array}$ & $\begin{array}{l}\text { Retrospective } \\
\text { case series }\end{array}$ & 20 & 2 Years & No description & $\begin{array}{l}\text { No variation of } \\
\text { tibial tunnel } \\
\text { position }\end{array}$ \\
\hline $\begin{array}{l}\text { Jung et al. } \\
\text { [18] }\end{array}$ & $\begin{array}{l}\text { Fibular head or tibial tunnel for } \\
\text { posterolateral corner } \\
\text { reconstruction }\end{array}$ & $\begin{array}{l}\text { Retrospective } \\
\text { case series }\end{array}$ & 39 & 2 Years & No description & $\begin{array}{l}\text { No variation of } \\
\text { tibial tunnel } \\
\text { position }\end{array}$ \\
\hline $\begin{array}{l}\text { Kim et al. } \\
{[20]}\end{array}$ & $\begin{array}{l}\text { Tibial tunnel single versus inlay } \\
\text { single versus inlay double }\end{array}$ & $\begin{array}{l}\text { Retrospective } \\
\text { case series }\end{array}$ & 29 & 2 Years & No description & $\begin{array}{l}\text { No variation of } \\
\text { tibial tunnel } \\
\text { position }\end{array}$ \\
\hline $\begin{array}{l}\text { Kim et al. } \\
{[21]}\end{array}$ & $\begin{array}{l}1 \text { versus } 2 \text { incision PCL } \\
\text { reconstruction }\end{array}$ & $\begin{array}{l}\text { Retrospective } \\
\text { case series }\end{array}$ & 55 & 2 Years & $\begin{array}{l}1.5 \mathrm{~cm} \text { below the articular } \\
\text { margin }\end{array}$ & $\begin{array}{l}\text { No variation of } \\
\text { tibial tunnel } \\
\text { position }\end{array}$ \\
\hline Li et al. [22] & $\begin{array}{l}\text { Hamstring graft versus LARS } \\
\text { artificial ligament }\end{array}$ & $\begin{array}{l}\text { Retrospective } \\
\text { case series }\end{array}$ & 36 & 2 Years & $\begin{array}{l}\text { Distal and lateral on } \\
\text { footprint, } 8-10 \mathrm{~mm} \text { from } \\
\text { articular joint }\end{array}$ & $\begin{array}{l}\text { No variation of } \\
\text { tibial tunnel } \\
\text { position }\end{array}$ \\
\hline $\begin{array}{l}\text { MacGillivray } \\
\text { et al. [25] }\end{array}$ & $\begin{array}{l}\text { Tibial inlay versus tibial tunnel } \\
\text { technique }\end{array}$ & $\begin{array}{l}\text { Retrospective } \\
\text { case series }\end{array}$ & 20 & 2 Years & No description & $\begin{array}{l}\text { No variation of } \\
\text { tibial tunnel } \\
\text { position }\end{array}$ \\
\hline $\begin{array}{l}\text { Wang et al. } \\
\text { [41] }\end{array}$ & $\begin{array}{l}\text { Autograft versus allograft PCL } \\
\text { reconstruction }\end{array}$ & $\begin{array}{l}\text { Prospective } \\
\text { randomized } \\
\text { study }\end{array}$ & 55 & 2 Years & $\begin{array}{l}1 \mathrm{~cm} \text { below the articular } \\
\text { surface of the medial } \\
\text { plateau }\end{array}$ & $\begin{array}{l}\text { No variation of } \\
\text { tibial tunnel } \\
\text { position }\end{array}$ \\
\hline $\begin{array}{l}\text { Wang et al. } \\
\text { [42] }\end{array}$ & $\begin{array}{l}\text { Single- versus double-bundle } \\
\text { PCL reconstruction }\end{array}$ & $\begin{array}{l}\text { Prospective } \\
\text { randomized } \\
\text { study }\end{array}$ & 35 & 2 Years & $\begin{array}{l}1 \mathrm{~cm} \text { below the articular } \\
\text { surface of the medial } \\
\text { plateau }\end{array}$ & $\begin{array}{l}\text { No variation of } \\
\text { tibial tunnel } \\
\text { position }\end{array}$ \\
\hline $\begin{array}{l}\text { Wong et al. } \\
\text { [43] }\end{array}$ & $\begin{array}{l}\text { Anteromedial versus } \\
\text { anterolateral transtibial } \\
\text { approach }\end{array}$ & $\begin{array}{l}\text { Prospective } \\
\text { randomized } \\
\text { study }\end{array}$ & 55 & 3 Years & $\begin{array}{l}1 \mathrm{~cm} \text { below the articular } \\
\text { surface of the medial } \\
\text { plateau }\end{array}$ & $\begin{array}{l}\text { No variation of } \\
\text { tibial tunnel } \\
\text { position }\end{array}$ \\
\hline
\end{tabular}

LARS ligament augmentation and reconstruction system

PCL bundles were in different planes on the posterior intercondylar fossa. Greiner et al. [14] determined the PCL insertion site using computed tomography scans and an additional anatomical reference, the posterior edge of the retrospinal surface.

In a radiological study, Racanelli and Drez [32] reproducibly identified PCL tibial attachment superior to and onto the posterior tibial ridge, and $2-3 \mathrm{~mm}$ lateral to the centre of the lateral tibial tubercle, with an error margin of $2.5 \mathrm{~mm}$. Similarly, Lorenz et al. [24] reported that the geometric centre of the tibial insertion was located at $51 \pm 2 \%$ of the total mediolateral width of the tibial plateau. In the sagittal plane, this point was $13 \pm 2 \%$ below the medial plateau tangent, using the total sagittal diameter of the tibial plateau as a reference.
Three biomechanical studies compared different graft placements in the PCL fovea and their impact on anteroposterior laxity control [4, 12, 27]. Galloway et al. [12] tested five tibial graft placements in the PCL fovea. The femoral insertion was placed at the isometric point, and the tibial insertion was moved either in the sagittal or frontal plane. There was no significant difference in anteroposterior laxity between the more anterior and posterior tunnel placement. A significant difference in laxity was found between medial and lateral placements from $30^{\circ}$ to $60^{\circ}$ of knee flexion: lateral displacement yielded better laxity control, but increased stress on the joint between $0^{\circ}$ and $50^{\circ}$ of flexion. Bomberg et al. [4] corroborated that tibial attachment variation in the sagittal plane had minor effects on graft isometry. Markolf et al. [27] placed the femoral 
Table 2 Placement of the PCL tibial insertion according to anatomical studies

\begin{tabular}{|c|c|c|c|c|c|}
\hline \multirow[t]{2}{*}{ Study } & \multirow[t]{2}{*}{ Study methodology } & \multirow{2}{*}{$\begin{array}{l}\text { Number } \\
\text { of knees }\end{array}$} & \multicolumn{3}{|l|}{ Posterior cruciate ligament } \\
\hline & & & PCL centre & Antero-lateral bundle centre & $\begin{array}{l}\text { Posterio-medial } \\
\text { bundle centre }\end{array}$ \\
\hline $\begin{array}{l}\text { Cosgarea } \\
\text { et al. [8] }\end{array}$ & Review study & $\mathrm{n} / \mathrm{a}$ & $\begin{array}{l}10-15 \mathrm{~mm} \text { under the articular } \\
\text { surface of the tibia }\end{array}$ & & \\
\hline \multirow[t]{2}{*}{$\begin{array}{l}\text { Edwards } \\
\text { et al. [9] }\end{array}$} & Cadaveric dissection & 39 & & $\begin{array}{l}\text { Posterior horn of the medial } \\
\text { meniscus is the anterior edge } \\
\text { of AL bundle }\end{array}$ & $\begin{array}{l}7 \mathrm{~mm} \text { under the } \\
\text { articular surface of } \\
\text { the tibia }\end{array}$ \\
\hline & & & & $\begin{array}{l}37 \mathrm{~mm} \text { from the medial edge } \\
\text { of the plateau }\end{array}$ & $\begin{array}{l}38 \mathrm{~mm} \text { from the } \\
\text { medial edge of the } \\
\text { plateau }\end{array}$ \\
\hline \multirow{2}{*}{$\begin{array}{l}\text { Girgis et al. } \\
\text { [13] }\end{array}$} & Dissection of cadaveric & 44 & On the retrospinal surface & & \\
\hline & and fresh knees & & $\begin{array}{l}\text { Extended for a few millimetres } \\
\text { onto the adjoining posterior } \\
\text { surface of the tibia }\end{array}$ & & \\
\hline \multirow[t]{4}{*}{$\begin{array}{l}\text { Greiner et al. } \\
\text { [14] }\end{array}$} & $\begin{array}{l}\text { CT scans of dissected } \\
\text { cadaveric knees }\end{array}$ & 10 & $\begin{array}{l}1.6 \mathrm{~mm} \text { inferior to the articular } \\
\text { surface of the plateau }\end{array}$ & & \\
\hline & & & $\begin{array}{l}46.1 \mathrm{~mm} \text { from the anterior } \\
\text { margin of the plateau }\end{array}$ & & \\
\hline & & & $\begin{array}{l}36.6 \mathrm{~mm} \text { from the medial edge of } \\
\text { the plateau }\end{array}$ & & \\
\hline & & & $49 \%$ of the width of the plateau & & \\
\hline $\begin{array}{l}\text { Moorman } \\
\text { et al. [28] }\end{array}$ & $\begin{array}{l}\text { Sectioning and } \\
\text { radiographic analysis } \\
\text { of cadaveric knees }\end{array}$ & 14 & $\begin{array}{l}7 \mathrm{~mm} \text { in front of the tibial } \\
\text { posterior cortex }\end{array}$ & & \\
\hline \multirow[t]{2}{*}{$\begin{array}{l}\text { Ramos et al. } \\
\text { [33] }\end{array}$} & Cadaveric dissection & 30 & $\begin{array}{l}15 \mathrm{~mm} \text { under the articular surface } \\
\text { of the tibia }\end{array}$ & & \\
\hline & & & $\begin{array}{l}10.3 \mathrm{~mm} \text { in front of the posterior } \\
\text { capsule }\end{array}$ & & \\
\hline \multirow[t]{2}{*}{$\begin{array}{l}\text { Sheps et al. } \\
{[35]}\end{array}$} & Cadaveric dissection & 10 & $\begin{array}{l}\text { Distal to cartilage tidemark and } \\
\text { posterior horns of menisci }\end{array}$ & & \\
\hline & & & $\begin{array}{l}\text { Proximal to palpable cortical } \\
\text { ridge in PCL fossa }\end{array}$ & & \\
\hline \multirow[t]{6}{*}{$\begin{array}{l}\text { Tajima et al. } \\
\text { [37] }\end{array}$} & Cadaveric dissection & 21 & & $\begin{array}{l}1.5 \mathrm{~mm} \text { under the articular } \\
\text { surface of the tibia }\end{array}$ & $\begin{array}{l}6 \mathrm{~mm} \text { under the } \\
\text { articular surface of }\end{array}$ \\
\hline & & & & $34.3 \mathrm{~mm}$ from the medial edge & \\
\hline & & & & of the plateau & $31.8 \mathrm{~mm}$ from the \\
\hline & & & & $\begin{array}{l}41.3 \mathrm{~mm} \text { from the anterior } \\
\text { margin of the plateau }\end{array}$ & $\begin{array}{l}\text { medial edge of the } \\
\text { plateau }\end{array}$ \\
\hline & & & & $\begin{array}{l}47 \% \text { of the width of the } \\
\text { plateau }\end{array}$ & $\begin{array}{l}47.1 \mathrm{~mm} \text { from the } \\
\text { anterior margin of } \\
\text { the plateau }\end{array}$ \\
\hline & & & & & $\begin{array}{l}44 \% \text { of the width of } \\
\text { the plateau }\end{array}$ \\
\hline \multirow[t]{4}{*}{$\begin{array}{l}\text { Takahashi } \\
\text { et al. [38] }\end{array}$} & Cadaveric dissection & 33 & & $\begin{array}{l}\text { The same level as the articular } \\
\text { surface of the tibia }\end{array}$ & $\begin{array}{l}4.6 \mathrm{~mm} \text { distal to the } \\
\text { articular surface of }\end{array}$ \\
\hline & & & & $\begin{array}{l}48.2 \mathrm{~mm} \text { from the medial edge } \\
\text { of the plateau. }\end{array}$ & $\begin{array}{l}\text { the tibia } \\
47.4 \mathrm{~mm} \text { from the }\end{array}$ \\
\hline & & & & $\begin{array}{l}51 \% \text { of the width of the } \\
\text { plateau }\end{array}$ & $\begin{array}{l}\text { medial edge of the } \\
\text { plateau }\end{array}$ \\
\hline & & & & & $\begin{array}{l}50 \% \text { of the width of } \\
\text { the plateau }\end{array}$ \\
\hline $\begin{array}{l}\text { Van } \\
\text { Dommelen } \\
\text { et al. [39] }\end{array}$ & Review study & $\mathrm{n} / \mathrm{a}$ & $\begin{array}{l}10 \mathrm{~mm} \text { distal to the articular } \\
\text { surface of the tibia }\end{array}$ & & \\
\hline
\end{tabular}


tunnel $5 \mathrm{~mm}$ distal to the geometric centre of the femoral PCL insertion, to simulate anterolateral bundle reconstruction. The tibial tunnel was positioned $5 \mathrm{~mm}$ medial or lateral to the geometric centre of the tibial insertion. Errors in mediolateral tunnel position did not significantly influence laxity control between $5^{\circ}$ and $120^{\circ}$ of knee flexion. However, medial displacement of the tunnel led to increased graft forces beyond $65^{\circ}$ of flexion.

\section{Discussion}

The most important finding of the present study is the lack of clinical research-based evidence for an optimal tibial tunnel placement in PCL reconstruction using the tibial tunnel technique. No clinical trial matched the inclusion criteria for the study. Several recommendations based on anatomical, radiological, or biomechanical investigations were identified in the literature [2, 4, 6-10, 12-14, 24, 25, 27, 28, 32-39], but they are sometimes contradictory and do not match the surgical recommendations of medical textbooks.

Cadaveric studies utilized various anatomical landmarks to describe the PCL insertion site. This probably reflects the difficulty in finding consistent and reliable landmarks. Many techniques used only one reference value, although at least two coordinates are necessary to define a point geographically, and more are needed for an accurate three-dimensional mapping as proposed by Tajima et al. [37], Takahashi et al. [38] and Greiner et al. [14]. These studies provided detailed descriptions of the tibial PCL insertion, but the anatomical landmarks proposed are not always suitable for arthroscopic surgery with the patient in supine position.

Radiological studies also attempted to identify landmarks for definition of the PCL tibial insertion site [24, 32]. However, they did not rely on identical reference points and did not distinguish between the anterolateral and posteromedial bundles. Two more recent radiological studies have distinguished between the two PCL bundles. Osti et al. [30] correlated radiography and descriptive anatomy and observed that the cross-sectional areas and femoral and tibial insertions for the anterolateral and posteromedial bundles were similar to, but smaller in area than those observed anatomically by Takahashi et al. [38], and the intercondylar depth of the two bundles was smaller than that observed radiologically by Lorenz et al. [24], with the insertion areas deeper into the intercondylar wall. Johannsen et al. [17] characterized the anterolateral and posteromedial bundles of the PCL radiologically and recommended that a single tibial tunnel should be located between 1 and $2 \mathrm{~mm}$ distal to the joint line on the anteroposterior view. It is not yet known whether this location is consistently reproducible during arthroscopic PCL reconstruction surgery and leads to effective maintenance of joint stability.
The biomechanical studies reviewed $[4,12,27]$ did not provide sufficient data to identify the optimal placement of the PCL tibial insertion for all degrees of knee flexion.

Several medical textbooks were also reviewed and demonstrated considerable variation in recommendations for tibial tunnel placement. Noyes et al. [29] and Strobel [36] placed the tibial guide at $12-20 \mathrm{~mm}$ distal to the joint line. Fanelli [10] suggested placement on the distal part of the PCL fovea to avoid the "killer turn" for the tendinous graft. Christel et al. [6] recommended placement in the distal third of the retrospinal area. Sekiya et al. [34] recommended that the transtibial guide pin should be placed $1 \mathrm{~cm}$ below the joint line. Kantaras and Johnson [19] suggested drilling the tibial tunnel distal and lateral to the medial meniscal root. Finally, Badet and Siegrist [2] positioned the tip of the guide $1.5 \mathrm{~cm}$ below the articular surface. However, none of these authors could rely on clinical evidence to inform their chosen placement of the tibial tunnel placement.

There is still a mismatch between surgical recommendations for tibial tunnel placement and biomechanical, radiological and anatomical data. This may be due to certain technical issues, such as prevention of the "killer turn" for the tendinous graft. Biomechanical studies show that anterior and posterior tibial tunnel position is less important than medial and lateral placement for laxity control, but they do not reflect behaviour of the graft in vivo. Different tunnel placements may change the length of the free intra-articular graft and the stiffness of the reconstruction and thus alter laxity control. Radiological landmarks may be helpful for tunnel placement, but have limited accuracy due to imaging quality within the surgical setting and use of simple two-dimensional images.

There was no significant difference in anteroposterior laxity between the more anterior and posterior tunnel placement. However, a significant difference in laxity was found between medial and lateral placements from $30^{\circ}$ to $60^{\circ}$ of knee flexion; lateral displacement yielded a better laxity control, but increased stress on the joint between $0^{\circ}$ and $50^{\circ}$ of flexion.

\section{Conclusions}

This systematic review did not identify an optimal tibial tunnel placement for arthroscopic PCL reconstruction using a tibial tunnel technique. In the absence of other clinical evidence, tunnel placement for PCL reconstruction should be anatomical as for ACL reconstruction. A detailed cartography of the PCL fovea is necessary to establish consistent, reproducible anatomical landmarks for surgery. Randomized clinical trials comparing at least two defined positions of the tibial tunnel graft on the retrospinal area 
during PCL reconstruction are needed, to determine whether the positions can be consistently achieved and result in effective, reliable maintenance of joint stability, and to evaluate complication rates.

Acknowledgments The authors thank Dagmar Gross for assistance with preparation of the manuscript.

Conflict of interest Each of the authors certifies that he or she has no commercial associations (e.g., consultancies, stock ownership, equity interest, patent/licensing arrangements, etc.) that might pose a conflict of interest in connection with the submitted article.

Open Access This article is distributed under the terms of the Creative Commons Attribution License which permits any use, distribution, and reproduction in any medium, provided the original author(s) and the source are credited.

\section{Appendix}

Original search strategy for MEDLINE (OVID)

Terms

("posterior cruciate ligament" [MeSH Terms] OR ("posterior"[All Fields] AND "cruciate"[All Fields] AND "ligament"[All Fields]) OR "posterior cruciate ligament"[All Fields]) OR PCL[All Fields] AND (Clinical Trial[ptyp] AND (English[lang] OR French[lang] OR German[lang] OR Italian[lang] OR Spanish[lang]) AND “adult"[MeSH Terms] AND (“1990/01/01”[PDAT]: “2011/10/01”[PDAT]))

\section{Limits}

Clinical trials

All adult: +19 years

English, German, Italian, French, Spanish

January 1990-September 2011

\section{Number}

Cochrane database of systematic reviews

Terms

Posterior cruciate ligament (all field)

Number

27

Cochrane central register of controlled trials

Terms

Posterior cruciate ligament (all field)

\section{Number}

Original search strategy for EMBASE

\section{Terms}

Posterior AND cruciate AND 'ligament'/exp AND [controlled clinical trial]/lim AND ([english]/lim OR [french]/lim OR [german]/lim OR [italian]/lim OR [spanish]/lim) AND ([adult]/lim OR [aged]/lim) AND [1990-2011]/py

\section{Limits}

Controlled clinical trials

January 1990-September 2011

Age: 18-64, 65, and more

Language: English, German, Italian, French, Spanish

Number

58

\section{References}

1. Ahn JH, Yoo JC, Wang JH (2005) Posterior cruciate ligament reconstruction: double-loop hamstring tendon autograft versus Achilles tendon allograft-clinical results of a minimum 2-year follow-up. Arthroscopy 21:965-969

2. Badet R, Siegrist O (2004) Techniques de reconstruction du ligament croisé postérieur. In: Neyret $\mathrm{P}$ (ed) Ligaments croisés du Genou: Cahiers d'enseignement de la Sofcot no 86. Elsevier Masson, Issy-les-Moulineaux, pp 183-193

3. Berg EE (1995) Posterior cruciate ligament tibial inlay reconstruction. Arthroscopy 11:69-76

4. Bomberg BC, Acker JH, Boyle J (1990) The effect of posterior cruciate ligament loss and reconstruction on the knee. Am J Knee Surg 3:85-96

5. Chen $\mathrm{CH}$, Chen WJ, Shih $\mathrm{CH}$ (2002) Arthroscopic reconstruction of the posterior cruciate ligament: a comparison of quadriceps tendon autograft and quadruple hamstring tendon graft. Arthroscopy 18:603-612

6. Christel P, Branfraux M, Djian P (2003) Traitement chirurgical des lésions du ligament croisé postérieur. In: Landreau P, Christel $\mathrm{P}$, Djian P (eds) Pathologie ligamentaire du genou. Springer, France, pp 475-498

7. Clancy WG Jr, Shelbourne KD, Zoellner GB, Keene JS, Reider B, Rosenberg TD (1983) Treatment of knee joint instability secondary to rupture of the posterior cruciate ligament. Report of a new procedure. J Bone Joint Surg Am 65:310-322

8. Cosgarea AJ, Jay PR (2001) Posterior cruciate ligament injuries: evaluation and management. J Am Acad OrthopSurg 9:297-307

9. Edwards A, Bull AM, Amis AA (2007) The attachments of the fibber bundles of the posterior cruciate ligament: an anatomic study. Arthroscopy 23:284-290

10. Fanelli GC (2001) Arthroscopically assisted posterior cruciate ligament reconstruction: transtibial tunnel technique. In: Fanelli GC (ed) Posterior cruciate ligament injuries-a practical guide to management. Springer, New York, pp 141-156

11. Freeman RT, Duri ZA, Dowd GS (2002) Combined chronic posterior cruciate and posterolateral corner ligamentous injuries: a comparison of posterior cruciate ligament reconstruction with and without reconstruction of the posterolateral corner. Knee 9:309-312 
12. Galloway MT, Grood ES, Mehalik JN, Levy M, Saddler SC, Noyes FR (1996) Posterior cruciate ligament reconstruction. An in vitro study of femoral and tibial graft placement. Am J Sports Med 24:437-445

13. Girgis FG, Marshall JL, Monajem A (1975) The cruciate ligaments of the knee joint. Anatomical, functional and experimental analysis. Clin Orthop Relat Res 106:216-231

14. Greiner P, Magnussen RA, Lustig S, Demey G, Neyret P, Servien E (2011) Computed tomography evaluation of the femoral and tibial attachments of the posterior cruciate ligament in vitro. Knee Surg Sports Traumatol Arthrosc 19:1876-1883

15. Harner CD, Hoher J (1998) Evaluation and treatment of posterior cruciate ligament injuries. Am J Sports Med 26:471-482

16. Hatayama K, Higuchi H, Kimura M, Kobayashi Y, Asagumo H, Takagishi K (2006) A comparison of arthroscopy single-and double-bundle posterior cruciate ligament reconstruction: review of 20 cases. Am J Orthop (Belle Mead NJ) 35:568-571

17. Johannsen AM, Anderson CJ, Wijdicks CA, Engebretsen L, LaPrade RF (2013) Radiographic landmarks for tunnel positioning in posterior cruciate ligament reconstrunction. Am J Sports Med 41:35-42

18. Jung YB, Jung HJ, Kim SJ, Park SJ, Song KS, Lee YS, Lee SH (2008) Posterolateral corner reconstruction for posterolateral rotatory instability combined with posterior cruciate ligament injuries: comparison between fibular tunnel and tibial tunnel techniques. Knee Surg Sports Traumatol Arthrosc 16:239-248

19. Kantaras A, Johnson D (2002) The medial meniscal root as a landmark for tibial tunnel position in the posterior cruciate ligament reconstruction. Arthroscopy 18:99-101

20. Kim SJ, Kim TE, Jo SB, Kung YP (2009) Comparison of the clinical results of three posterior cruciate ligament reconstruction techniques. J Bone Joint Surg Am 91:2543-2549

21. Kim SJ, Shin SJ, Kim HK, Jahng JS, Kim HS (2000) Comparison of 1- and 2-incision posterior cruciate ligament reconstructions. Arthroscopy 16:268-278

22. Li B, Wen Y, Wu H, Qian Q, Wu Y, Lin X (2009) Arthroscopic single-bundle posterior cruciate ligament reconstruction: retrospective review of hamstring tendon graft versus LARS artificial ligament. Int Orthop 33:991-996

23. Lipscomb AB Jr, Anderson AF, Norwig ED, Hovis WD, Brown DL (1993) Isolated posterior cruciate ligament reconstruction. Long-term results. Am J Sports Med 21:490-496

24. Lorenz S, Elser F, Brucker PU, Obst T, Imhoff AB (2009) Radiological evaluation of the anterolateral and posteromedial bundle insertion sites of the posterior cruciate ligament. Knee Surg Sports Traumatol Arthrosc 17:683-690

25. MacGillivray JD, Stein BE, Park M, Allen AA, Wickiewicz TL, Warren RF (2006) Comparison of tibial inlay versus transtibial techniques for isolated posterior cruciate ligament reconstruction: minimum 2-year follow-up. Arthroscopy 22:320-328

26. Markolf KL, McAllister DR, Young CR, McWilliams J, Oakes DA (2003) Biomechanical effects of medial-lateral tibial tunnel placement in posterior cruciate ligament reconstruction. J Orthop Res 21:177-182

27. Markolf KL, Feeley BT, Jackson SR, McAllister DR (2006) Where should the femoral tunnel of a posterior cruciate ligament reconstruction be placed to best restore anteroposterior laxity and ligament forces? Am J Sports Med 34:604-611
28. Moorman CT, Murphy Zane MS, Bansai S, Cina SJ, Wickiewicz TL, Warren RF, Kaseta MK (2008) Tibial insertion of the posterior cruciate ligament: a sagittal plane analysis using gross, histologic, and radiographic methods. Arthroscopy 24:269-275

29. Noyes F, Barber-W S, Grood E (2001) Newer concept of the treatment of posterior cruciate ligament ruptures. In: Insall $\mathrm{JN}$, Scott WN (eds) Surgery of the knee, 3rd edn. Churchill Livingstone, New York, pp 841-878

30. Osti M, Tschann P, Kunzel KH, Benedetto KP (2012) Anatomic characteristics and radiographic references of the anterolateral and posteromedial bundles of the posterior cruciate ligament. Am J Sports Med 40:1558-1563

31. Park SE, Stamos BD, DeFrate LE, Gill TJ, Li G (2004) The effect of posterior knee capsulotomy on posterior tibial translation during posterior cruciate ligament tibial inlay reconstruction. Am J Sports Med 32:1514-1519

32. Racanelli JA, Drez D Jr (1994) Posterior cruciate ligament tibial attachment anatomy and radiographic landmarks for tibial tunnel placement in PCL reconstruction. Arthroscopy 10:546-549

33. Ramos LA, de Carvalho RT, Cohen M, Abdalla RJ (2008) Anatomic relation between the posterior cruciate ligament and the joint capsule. Arthroscopy 24:1367-1372

34. Sekiya JK, West RV, Ong BC, Irrgang JJ, Fu FH, Harner CD (2005) Clinical outcomes after isolated arthroscopic single-bundle posterior cruciate ligament reconstruction. Arthroscopy 21:1042-1050

35. Sheps DM, Otto D, Fernhout M (2005) The anatomic characteristics of the tibial insertion of the posterior cruciate ligament. Arthroscopy 21:820-825

36. Strobel MJ (2001) Posterior Cruciate Ligament. In: Strobel M (ed) Manual of arthroscopic surgery. Springer, Berlin, pp 571641

37. Tajima G, Nozaki M, Iriuchishima T, Ingham SJ, Shen W, Smolinski P, Fu FH (2009) Morphology of the tibial insertion of the posterior cruciate ligament. J Bone Joint Surg Am 91:859-866

38. Takahashi M, Matsubara T, Doi M, Suzuki D, Nagano A (2006) Anatomical study of the femoral and tibial insertions of the anterolateral and posteromedial bundles of human posterior cruciate ligament. Knee Surg Sports Traumatol Arthrosc 14: $1055-1059$

39. Van Dommelen BA, Fowler PJ (1989) Anatomy of the posterior cruciate ligament. A review. Am J Sports Med 17:24-29

40. Voos JE, Mauro CS, Wente T, Warren RF, Wickiewicz TL (2012) Posterior cruciate ligament anatomy, biomechanics, and outcomes. Am J Sports Med 40:222-231

41. Wang CJ, Chan YS, Weng LH, Yuan LJ, Chen HS (2004) Comparison of autogenous and allogenous posterior cruciate ligament reconstructions of the knee. Injury 35:1279-1285

42. Wang CJ, Weng LH, Hsu CC, Chan YS (2004) Arthroscopic single- versus double-bundle posterior cruciate ligament reconstructions using hamstring autograft. Injury 35:1293-1299

43. Wong T, Wang CJ, Weng LH, Hsu SL, Chou WY, Chen JM, Chan YS (2009) Functional outcomes of arthroscopic posterior cruciate ligament reconstruction: comparison of anteromedial and anterolateral trans-tibia approach. Arch Orthop Trauma Surg $129: 315-321$ 